\title{
Relevance and Effectiveness of Tourism Management Curriculum vis-à-vis Graduates Employability
}

\author{
Dr. Eric A. Matriano, Dr. Rowena F. Shabazz, Dr. Salvacion A. Nihei and Ms. Merleen Labis
}

Abstract — This study determined the relevance andeffectiveness of Bachelor of Science Curriculum based on the traced employment status of graduates of Columban College, Inc. from $2012-2015$.

The descriptive-survey type of research was utilized with fifty-two (52) graduates of BSTM Program who was traced out of the 89 graduates as respondents. Data were analyzed using Percentage, Mean, and Weighted Mean.

Majority of the respondents' main reason for enrolling in BS Tourism Management is the opportunity for employment and travel abroad. Majority of the graduates are working on a regular/permanent status in a tourism-related job in the country and stayed in that job for that main reason and because of salary and benefits. They found their first job through the information received from friends, relatives and acquaintances that there was employment hiring in less than a year after graduation and stayed in their first job a year or two with an initial gross income within the minimum wage bracket. In terms of BSTM relevance, most of the respondents perceived that the Program is relevant to their first and present job. The following competencies and skills are relevant in their jobs: interpersonal skills, ability to speak, personal quality of being sociable, the ability to solve organizational problems and challenges by identifying problems and implementing corrective and/or mitigating actions and measures.

The integration of national and international hospitality and tourism issues and challenges in instruction is very much effective as well as provision of pre-service trainings (which includes seminars, workshops, travel, study tour, among others) for the acquisition of knowledge, skills and values needed in future jobs. The facilities for support services such as health, guidance, employment and placement services, canteen, etc. are also very much effective in the delivery of the Program. All the graduates suggested that the school must provide more exposure/trips/travel for major courses and it must install computers with reservation software for travel management course.

The findings imply that effective implementation of the Program also provides opportunities for students to develop their general intellectual capacities for life-long learning. For example, it promotes communication skills, interpersonal skills, information processing skills, problem solving skills and decision-making skills, recognize the importance of being a self-motivated problem-solver and life-long learner.

Keywords-Tourism Management, curriculum relevance and effectiveness, employability, tracer study, descriptive-survey, Olongapo City

Eric Agullana Matriano, Columban College, Inc, Philippines. He is the Dean and Research Coordinator of the College of Business and Accountancy, and a professor of Graduate School

\section{INTRODUCTION}

Tourism education at universities tends to focus on enabling students for future careers in the industry. Little attention has been devoted to the relevance and effectiveness of tourism education.

Tourism and hospitality are considered as major industries in the world, which are "in large part responsible for much economic growth, balance of payments, employments and regional balance in their countries [1]. Tourism industry is one of the world's biggest industries, of which hospitality industry can be considered as a part. According to the World Travel and Tourism Council Report of 2013, tourism contributed \$6.6 trillion in economic activity and provided 261 million jobs (direct and indirect). The amount of jobs offered by tourism is $8.7 \%$ of the total employment and the sector's contribution accounts for $9.3 \%$ of the world total GDP in 2012. The numbers are expected to rise by $1.7 \%$ and $3.2 \%$ by 2013 . Overall, the industry is estimated to provide more than 8.5 million new jobs annually until this year. The number of workers employed in hospitality services, representing hotels and restaurants is higher than in any other sectors of tourism industry. Other income sources of tourism are rent, sales, profit and taxes. The sources are generated by different subjects involving the industry for example landowners for building, car parking, campsites, sellers or owners of accommodations or restaurants and government, etc. [2]

Tourism in Olongapo City and its nearby Subic Bay Freeport Zone has seen growth over the last couple of years. While the city still relies on the Freeport for most of the employment of its residents, it had to undertake steps towards self-reliance. Towards this end, a full blast infrastructure program was initiated to complement existing tourism facilities and to promote the city as an all-year-round services and leisure center. This included the construction of a convention center, a museum, a sports and civic center, and a mall. With this, there is a great demand to produce graduates that will fill the demand for workers in the tourism sector.

Tourism education began as a development of technical/vocational schools in Europe. These schools emphasised training in core competencies such as hospitality, hotel management and related business skills [3][4]. Interest and demand from the public and private sectors impelled rapid growth of tourism studies and the development, and establishment, of departments of travel and tourism at institutions of higher education in addition to technical schools. 
While these programmes meet actual needs in training and education, there have been discussions on the proper place of such programmes. Debates over tourism programmes at universities appear to centre on the balance between vocational and academic focus. Tourism courses in higher education are often referred to as vocational [5] with educators focusing on producing skilled and knowledgeable managerial personnel for the industry. This emphasis has given short shrift to the value or meaning of tourism education.

Balancing the vocational and liberal aspects of tourism education is vital to producing a well-rounded graduate. This balance develops students who are broadly educated and knowledgeable about, and responsible in, tourism development as well as occupationally functional in tourism [6]. Concentrating on just the vocational impoverishes students and renders them less likely to be able to respond to stakeholders in a developing tourist society. Originating from technical training schools in Europe as a result of perceived need for trained workers, tourism curriculum has been dominated by a focus on specific occupational skills. Growth of these programmes in higher education has been driven by developments in the tourism industry.

It is noted that internships and apprenticeships in the industry, as well as academic subjects closely related to specific needs in the field such as: marketing; finance; management; and human resources; improve student development and competence. Schools have developed strong connections with the industry as a result of internships and industry specific education. Students have benefited because they are very employable, with management knowledge, experience and related interpersonal skills. Students have the expectation of high employability because of the vocational emphasis in tourism programmes. Internships also increase the ability of students to critically reflect on the tourism business [7].

It is reported on a successful example of a partnership between a university and a rural area in developing tourism knowledge in the students and for the community. Students conducted a destination analysis as a capstone activity for a tourism degree, providing them with "the skills, abilities and crucial understanding and appreciation of the tourism environment required by the industry". This interdependency of academia and industry typically results in production of employable students. [8]

The relatively high employment rate of tourism graduates can be attributed to acquisition of useful skills and practical experience in the industry as a result of curriculum. Practitioners may also have influence on courses [9].

Some researchers' interests have led to the evaluation of tourism education programmes. A study examined the relevance of academic tourism education to the occupation as a whole. It determined that the majority of industry professionals indicated the relevance of academic subjects to their career. It states that generic academic knowledge such as marketing, recreation, business, economics and others, can be applied to context specific work. However, jobs in tourism are not necessarily similar - tourism includes a variety of jobs that require the application of different types of academic knowledge bases, suggesting that tourism education includes a variety of transferable subjects.[10]

Columban College is one of the colleges in the city that offers Tourism programs. Every year it produces graduates that are set to find employment in their chosen careers. However, there are cases that this is not achieved. A lot of graduates face difficulties. Therefore, in this thesis, the main purpose is to create a brief picture of Columban College's Tourism students' expectation as well as difficulties they face after graduation when entering the tourism sector. This paper attempts to promote awareness of overlooked perspectives and critical issues in tourism management education by examining possible approaches to educating future tourism professionals. It discusses Tourism Management relevance from the perspective of employability as the primary goal.

\section{OBJECTIVE OF THE STUDY}

This study determined the relevance and effectiveness of Bachelor of Science Curriculum based on the traced employment status of graduates of Columban College, Inc. from $2013-2016$.

The employment status of the respondents were surveyed in terms of present employment status, present occupation, reasons for staying on the job, number of years in the first job, ways of finding the first job, number of months/ years in landing the first job, and initial gross monthly income in the first job after college. The assessment of the program effectiveness by the graduates was focused on the relevance to their first job, competencies/ skills learned as used in their job, delivery of instruction, pre-service training and practicum experience, and learning environment and facilities.

\section{Methodology}

The descriptive-survey type of research was utilized with fifty-two (52) graduates of BSTM Program who was traced out of the 89 graduates from Academic Year 2012 to 2015 as respondents. Standard Graduate Tracer Survey (GTS) instrument provided by the Commission on Higher Education was used with some modifications based on the CMO \# 30, series 2016. Data were primarily gathered using the said survey-questionnaire which administered personally (face-to-face) or sent via e-mail and chat; triangulated with informal interview, observation and document analysis. Data were analyzed using Percentage, Mean, and Weighted Mean.

\section{RESULTS AND DISCUSSION}

\section{A. Profile of the Respondents}

Majority of the BSTM graduates were still single, 42 or $80.77 \%$, only 8 or $15.38 \%$ were married. There were 47 or $90.38 \%$ female respondents and only 5 or $9.62 \%$ male respondents. The main reasons why they took the program because of the opportunity for employment/travel abroad, status or prestige of the profession, peer influence and prospect for immediate employment. 


\section{B. Employment Status of the BSTM Graduates}

1. Present Employment Status. Majority, 33 or $63.46 \%$ were regular or permanent in their jobs, 6 or $11.54 \%$ were probationary or temporary, 5 or $9.62 \%$ were self-employed and 3 or $5.77 \%$ were not employed. Majority or 37 of them works in the Philippines.

2. Present Occupation. Majority (34 or $77.27 \%$ ) of those who were employed either as permanent/regular, casual, contractual, seasonal or probationary are working in tourism-related employment.

3. Reasons for Staying in the Job. Out of the 44 respondents, 13 or $29.55 \%$ said they stayed in their present job because it is related to their course/program of study, 12 or $27.27 \%$ said it is because of salary and benefits they received from the companies.

4. Number of Years in the First Job. There were 49 graduates who have had their first job after graduation; 18 or $36.73 \%$ of which worked in their first job after graduation within a period of 1 to 2 years and 13 or $26.53 \%$ in less than a year.

5. Ways in Finding the First Job. Fifteen (15) or $30.61 \%$ have found their first job because of the information received from friends, relatives and acquaintances that there was employment hiring.

6. Number of Months/Years in Landing on the First Job. Most of them, 18 or $36.73 \%$ took 7 to 9 months before getting first job and only one or $2.04 \%$ took 3 to 4 years in landing her first job.

7. Initial Gross Monthly Income in their First Job. Most of them, 20 or $40.82 \%$ have their initial gross monthly salary in their first job between Php 10,000 and Php 11,999 . The average initial gross monthly salary in their first job is Php 12,225.

\section{Assessment of Graduates on the Perceived Program} Relevance of BS Tourism Management

1. Relevance to their First and Present Job. In terms of degree of relevance of the BSTM Program to their first job, 16 or $32.65 \%$ said that their Program is relevant; and in terms of degree of relevance of the BSTM Program to their present job, 18 or $40.91 \%$ said it is relevant.

2. Competencies/ Skills Learned as Used in Their Present Job. In terms of the basic competencies, the BSTM graduates assessed the interpersonal skills or the ability to work well with others as "Very Much Relevant" with a weighted mean of 3.89. In terms of skills and personal qualities learned, they perceived that the following are "Very Much Relevant" in their present job: ability to speak $(\mathrm{WX}=3.95)$ and personal quality of being sociable (WX $=3.88$. The basic skill of performing arithmetic and mathematical operations was given the lowest rating of 2.18 , with a descriptive rating of "Somewhat Relevant." In terms of professional specific competencies, the respondents believed that their ability to solve organizational problems and challenges by identifying problems (WX = 3.76) and implementing corrective and/or mitigating actions and measures $(\mathrm{WX}=3.75)$ were rated to be "Very Much Relevant."

The overall weighted mean for the relevance of basic skills acquired and learned during college days as applied in their present job was 3.44, for skills and personal qualities was 3.58 and for professional specific competencies was 3.67 - all with descriptive rating of "Very Much Relevant."

TABLE I. COMPETENCIES AND SKILLS LEARNED

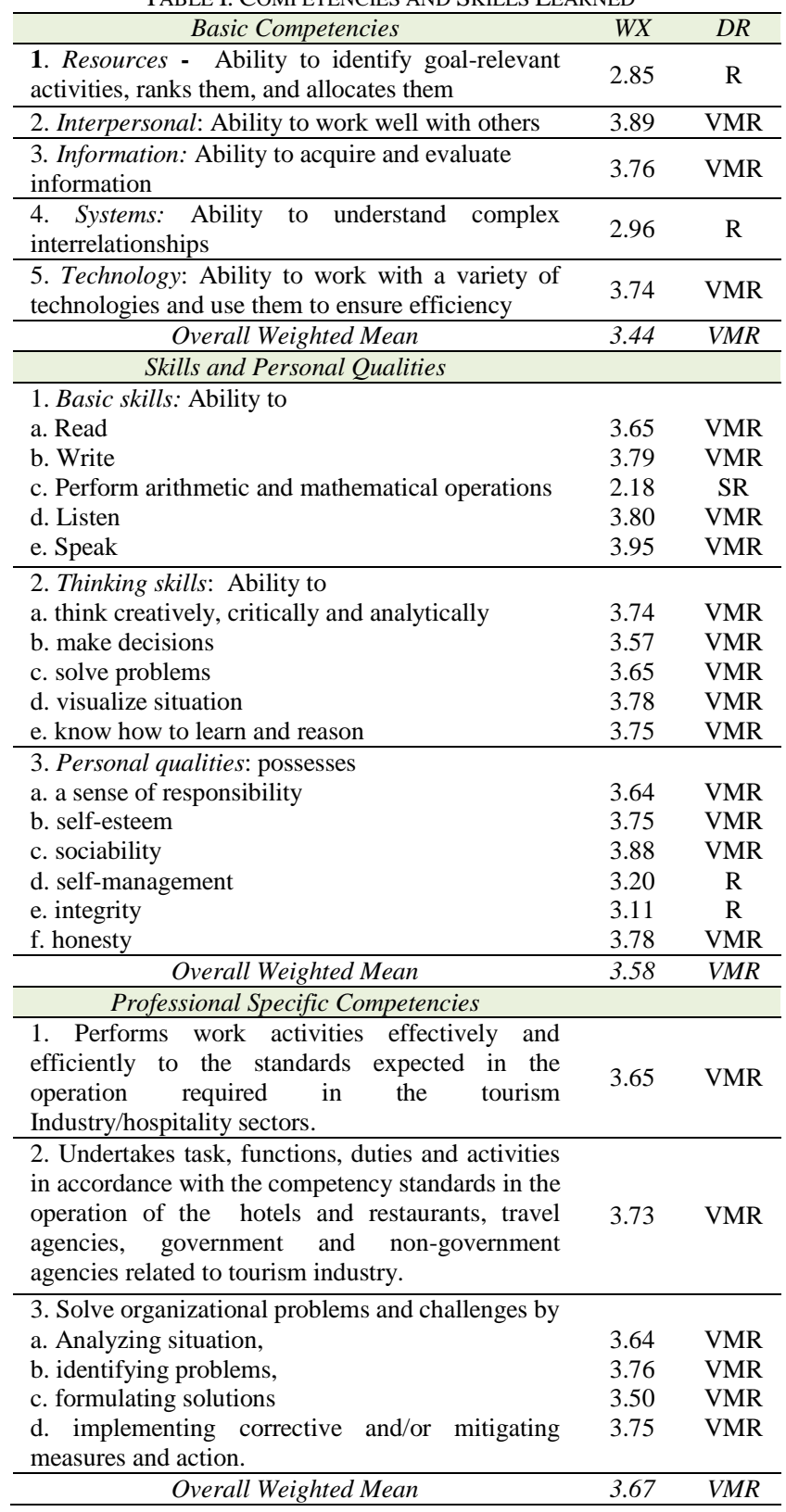

3. Delivery of Instruction. The graduates of the Program believed that the integration of national and international hospitality and tourism issues and challenges in instruction is very much effective with a weighted mean of 3.65. The overall weighted mean was 3.45 with a descriptive rating of "Very Much Effective." 
TABLE II. ASSESSMENT ON THE DELIVERY OF INSTRUCTION

\begin{tabular}{lcc}
\hline \multicolumn{1}{c}{ Delivery of Instruction } & $W X$ & $D R$ \\
\hline $\begin{array}{l}\text { 1. Curriculum and instruction is competency-based } \\
\text { where competencies being developed match the } \\
\text { international competency standards need by the } \\
\text { hospitality and tourism industry. }\end{array}$ & 3.55 & VME \\
\hline $\begin{array}{l}\text { 2. Job readiness is the focus of the curriculum and } \\
\text { instruction. }\end{array}$ & 3.58 & VME \\
\hline $\begin{array}{l}\text { 3. Delivery of instruction is industry-driven and } \\
\text { performance-based. }\end{array}$ & 3.53 & VME \\
\hline $\begin{array}{l}\text { 4. Instruction ensures acquisition of knowledge/ } \\
\text { concepts, skills and values needed in future } \\
\text { employment. }\end{array}$ & 3.54 & VME \\
\hline $\begin{array}{l}\text { 5. Different strategies and methods of lesson } \\
\text { delivery is used in instruction. }\end{array}$ & 3.10 & $\mathrm{E}$ \\
\hline $\begin{array}{l}\text { 6. Instruction focuses on learners' needs and } \\
\text { abilities. }\end{array}$ & 3.12 & $\mathrm{E}$ \\
\hline $\begin{array}{l}\text { 7. Individualized and group instruction are utilized } \\
\text { to ensure maximum learning. }\end{array}$ & 3.48 & $\mathrm{VME}$ \\
\hline $\begin{array}{l}\text { 8. Instruction integrates national and international } \\
\text { hospitality and tourism issues and challenges. }\end{array}$ & 3.65 & $\mathrm{VME}$ \\
\hline $\begin{array}{l}\text { 9. Instruction is supported by co-curricular activities } \\
\text { to enhance learning and interest to the Program. }\end{array}$ & 3.52 & $\mathrm{VME}$ \\
\hline $\begin{array}{l}\text { 10. Learning is measured and assessed using variety } \\
\text { of ways - including authentic, outcomes-based and } \\
\text { performance-based. }\end{array}$ & 3.47 & $\mathrm{VME}$ \\
\hline \begin{tabular}{l} 
Overall Weighted Mean \\
\hline
\end{tabular} & VME \\
\hline
\end{tabular}

4. Pre-service Training and Practicum Experience. The graduates assessed that pre-service trainings (which includes seminars, workshops, travel, study tour, among others) are provided for the acquisition of knowledge, skills and values needed in future jobs which are very much effective with a weighted mean of 3.83. The overall computed weighted mean was 3.45 with a descriptive rating of "Very Much Effective."

TABLE III. ASSESSMENT ON THE PRE-SERVICE TRAINING AND PRACTICUM EXPERIENCE

\begin{tabular}{lcc}
\hline \multicolumn{1}{c}{ Pre-Service Training and Practicum Experience } & $W X$ & $D R$ \\
\hline $\begin{array}{l}\text { 1. Pre-service trainings (which includes seminars, } \\
\text { workshops, travel, study tour, among others) are } \\
\text { provided for the acquisition of knowledge, skills } \\
\text { and values needed in future jobs. }\end{array}$ & 3.83 & VME \\
\hline $\begin{array}{l}\text { 2. Pre-service trainings are relevant in } \\
\text { understanding the hospitality and tourism } \\
\text { industry. }\end{array}$ & 3.68 & $\mathrm{VME}$ \\
\hline $\begin{array}{l}\text { 3. Pre-service trainings provide opportunities for } \\
\text { growth and development of learners. }\end{array}$ & 3.53 & $\mathrm{VME}$ \\
\hline $\begin{array}{l}\text { 4. Practicum experiences is relevant to the } \\
\text { Program. }\end{array}$ & 3.74 & $\mathrm{VME}$ \\
\hline $\begin{array}{l}\text { 5. Practicum experiences are significant to future } \\
\text { employment. }\end{array}$ & 3.80 & $\mathrm{VME}$ \\
\hline $\begin{array}{l}\text { 6. Practicum experiences develop proper work } \\
\text { habit and attitude. }\end{array}$ & 3.78 & $\mathrm{VME}$ \\
\hline $\begin{array}{l}\text { 7. Practicum hours are enough and pre-service } \\
\text { trainings are adequate to gain meaningful work } \\
\text { experience. }\end{array}$ & 3.57 & $\mathrm{VME}$ \\
\hline \multicolumn{1}{c}{ Overall Weighted Mean } & 3.45 & VME \\
\hline
\end{tabular}

5. Learning Environment and Facilities. The respondents assessed that the facilities for support services such as health, guidance, employment and placement services, canteen, etc. are very much effective in the delivery of the Program. The overall weighted mean was 3.51 with a descriptive rating of "Very Much Effective."
TABLE IV. ASSESSMENT ON LEARNING ENVIRONMENT AND FACILITIES

\begin{tabular}{|c|c|c|}
\hline Learning Environment and Facilities & $\mathbf{W X}$ & DR \\
\hline $\begin{array}{l}\text { 1. The learning environment, including the } \\
\text { classrooms and laboratories are safe and } \\
\text { conducive. }\end{array}$ & 3.78 & VME \\
\hline $\begin{array}{l}\text { 2. The laboratory (Travel Bureau) is well } \\
\text { equipped and ideal for simulation as travel } \\
\text { agency/services. }\end{array}$ & 2.64 & $\mathrm{E}$ \\
\hline $\begin{array}{l}\text { 3. The laboratory (CC Hotel) is } \\
\text { well-equipped and ideal for simulation on } \\
\text { front office services, culinary, event } \\
\text { management, etc. }\end{array}$ & 3.73 & VME \\
\hline 4. The campus security is ensured. & 3.56 & VME \\
\hline $\begin{array}{l}\text { 5. Library materials and instructional media } \\
\text { are adequate and useful to learning. }\end{array}$ & 3.82 & VME \\
\hline $\begin{array}{l}\text { 6. Other facilities such as halls, gym, AVR, } \\
\text { etc. are provided in support to instruction }\end{array}$ & 3.74 & VME \\
\hline $\begin{array}{l}\text { 7. Other facilities for support services such as } \\
\text { health, guidance, employment and placement } \\
\text { services, canteen, etc. are provided for } \\
\text { availment. }\end{array}$ & 3.85 & VME \\
\hline Overall Weighted Mean & 3.51 & $V M E$ \\
\hline
\end{tabular}

\section{Suggestions Given by the Graduates to Improve the Effectiveness of the BSTM Program}

All the respondents suggested that the school must provide more exposure/trips/travel for major courses and 43 or $82.69 \%$ of them suggested that computers with reservation software for travel management course must be provided for simulation activities in the Travel Bureau.

\section{E. Implications of the Findings}

The findings imply that effective implementation of the Program also provides opportunities for students to develop their general intellectual capacities for life-long learning. For example, it promotes communication skills, interpersonal skills, information processing skills, problem solving skills and decision-making skills, recognize the importance of being a self-motivated problem-solver and life-long learner.

\section{CONCLUSIONS}

Majority of the respondents are single, female and whose main reason for enrolling in BS Tourism Management is the opportunity for employment and travel abroad. Majority of the graduates are working on a regular/permanent status in a tourism-related job in the country and stayed in that job for that main reason and because of salary and benefits. They found their first job through the information received from friends, relatives and acquaintances that there was employment hiring in less than a year after graduation and stayed in their first job a year or two with an initial gross income within the minimum wage bracket.

In terms of BSTM relevance, most of the respondents perceived that the Program is relevant to their first and present job. The following competencies and skills are relevant in their jobs: interpersonal skills, ability to speak, personal quality of being sociable, the ability to solve organizational problems and challenges by identifying problems and implementing corrective and/or mitigating actions and measures.

The integration of national and international hospitality and tourism issues and challenges in instruction is very much effective as well as provision of pre-service trainings (which 
includes seminars, workshops, travel, study tour, among others) for the acquisition of knowledge, skills and values needed in future jobs. The facilities for support services such as health, guidance, employment and placement services, canteen, etc. are also very much effective in the delivery of the Program. All the graduates suggested that the school must provide more exposure/trips/travel for major courses and it must install computers with reservation software for travel management course.

Effective delivery and implementation of BSTM program must be continuously ensured to make its graduates relevant to the labor market of hospitality and tourism sector.

\section{ACKNOWLEDGMENT}

The author acknowledges the College of Business and Accountancy, Columban College for some data used in this study and for funding the study; and the selected students of the College of Business and Accountancy for data gathering.

\section{REFERENCES}

[1] Lockwood, A and Medlik, S. 2001. Tourism and Hospitality in the 21st Century. Great Britain: MPG books Ltd Cornwall

[2] Swain, S.K and Mishra, J.M. 2012. Tourism Principles and Practices. New Delhi: Oxford University Express

[3] Butler, R. W. (1999) Understanding Tourism. In E. L. Jackson and Burton, T. L. (Eds.), Leisure Studies: prospects or the twenty-first century, (pp97-116). State College, PA: Venture.

[4] Morgan, M. (2004) From Production Line to Drama School: Higher Education for the Future of tourism. International Journal of Contemporary Hospitality Management, Vol. 16(2), pp91-99

https://doi.org/10.1108/09596110410519973

[5] Busby, G. (2001) Vocationalism in Higher Level Tourism Courses: the British perspective. Journal of Further and Higher Education, Vol. 25(1), 29-43.

https://doi.org/10.1080/03098770020030489

[6] Lewis, A. (2005) Rationalising a Tourism Curriculum for Sustainable Tourism Development in Small Island States: A Stakeholder Perspective. Journal of Hospitality, Leisure, Sports and Tourism Education, Vol. 4(2), pp4-15

https://doi.org/10.3794/johlste.42.93.

[7] Tribe, J. (2001) Research Paradigms and the Tourism Curriculum. Journal of Travel Research, Vol. 39, 442-448. https://doi.org/10.1177/004728750103900411

[8] Croy, W. G. and Hall, C. M. (2003) Developing a Tourism Knowledge: Educating the Student, Developing the Rural Area. Journal of Teaching in Travel and Tourism, Vol. 3(1), 3-24.
https://doi.org/10.1300/J172v03n01_02

[9] Busby, G. (2003) Tourism degree internships: a longitudinal study. Journal of Vocational Education and Training, Vol. 55(3), 319-333. https://doi.org/10.1080/13636820300200232

[10] Churchward, J. and Riley, M. (2002) Tourism Occupations and Education: An Exploration Study. International Journal of Tourism Research, Vol. 4, 77-86.

https://doi.org/10.1002/jtr.361

\section{AUTHORS}

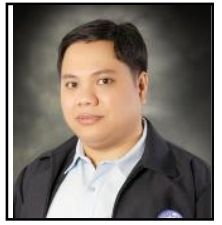

Prof. Eric A. Matriano, Ed. D., Ph. D. is a graduate of Doctor of Education at Columban College, Inc. in 2002 and Doctor of Philosophy major in Business Management at Manuel L. Quezon University in 2014. $\mathrm{He}$ finished Bachelor of Arts in General Science in 1994 and took Master's of Arts in Education major in Science Education and Master's of Business

Administration

$\mathrm{He}$ is one of the awardees for the Top Management Program at the Asian Institute of Management under Commission on Higher Education's Faculty Development Scholarship Program for K-12 Transition. He is book co-author of Chemistry Manual and Work-Text, Environmental Science: An Inquiry-Based Approach and Research Writing Made Easy for Business and Hospitality Students. He is currently the Dean and Research Coordinator of the College of Business and Accountancy at Columban College, Inc.

Dr. Matriano is also a graduate school professor, research committee reviewer, statistician, seminar-workshop speaker and multi-awarded research presenter.

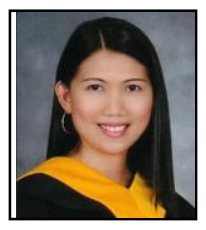

Prof. Rowena F. Shabazz, is a graduate of Doctor of Education at Columban College, Inc. in 2013. She finished Bachelor of Science in Tourism in 1998 and Master's degree in Business Administration in 2010. She is presently the chairperson of the Tourism Management Program of Columban College and a member of the Regional Quality Assurance Team of the Commission on Higher Education, Region 3.

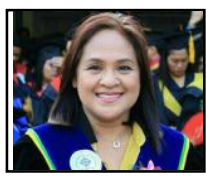

Prof. Salvacion A. Nihei, is a graduate of Doctor of Education at Columban College, Inc. in 2014. She finished Bachelor of Arts in English in 1997 and took Master's of Arts in Education major in Language Teaching in 2010. She also holds another Bachelor's degree in Tourism Management. At present, she is finishing her second Master's degree in Business Administration. She teaches Nihonngo, English courses and Tourism Management courses.

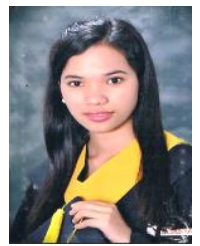

Prof. Merleen V. Labis is a graduate of BS tourism and Master in Business Administration at Columban College, Inc. She is an experienced travel management practitioner who worked as supervisor in a Travel Agency. She is a part-time college professor of Columban College, Inc. 